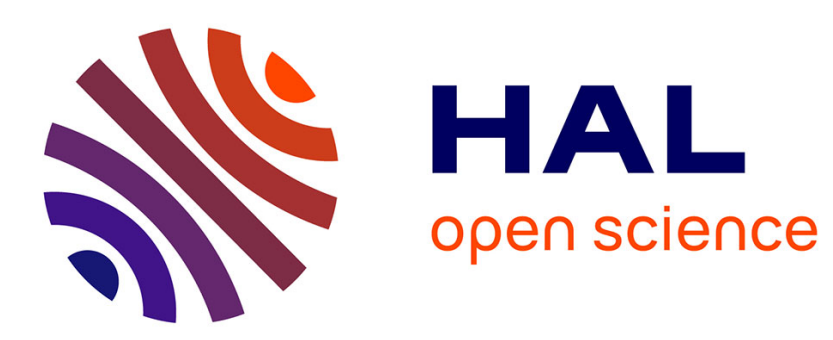

\title{
Pupils' Participation in French Secondary Schools: the interplay between tradition and innovation
}

\author{
Valérie Becquet
}

\section{To cite this version:}

Valérie Becquet. Pupils' Participation in French Secondary Schools: the interplay between tradition and innovation. Patricia Loncle; Gerrit Jackson; Virginie Muniglia. Youth participation in Europe. Beyond discourses, practices and realities, Policy Press, 2012, 9781447300182. 10.1332/policypress/9781447300182.003.0013 . hal-03147490

\section{HAL Id: hal-03147490 \\ https://hal.science/hal-03147490}

Submitted on 19 Feb 2021

HAL is a multi-disciplinary open access archive for the deposit and dissemination of scientific research documents, whether they are published or not. The documents may come from teaching and research institutions in France or abroad, or from public or private research centers.
L'archive ouverte pluridisciplinaire HAL, est destinée au dépôt et à la diffusion de documents scientifiques de niveau recherche, publiés ou non, émanant des établissements d'enseignement et de recherche français ou étrangers, des laboratoires publics ou privés. 
Part. 4: Participation and learning 


\section{Chapter 13: Pupils' Participation in French Secondary Schools: the interplay between tradition and innovation}

\section{Valérie Becquet}

\section{Introduction}

The analysis of youth participation In France, whether directed towards political, associative or protest practices (Becquet, 2009b; Muxel, 2010; Roudet, 2004) or towards institutional programs (Becquet, 2005a; Becquet, 2006, Loncle, 2008) often leaves aside participation in schools. Yet school participation involves a wide range of young people: the pupils in secondary schools. These young people often combine in school participation with out of school participation, or move from one to the other (Guillaume and Verdon, 2007; Becquet, 2005b). Moreover, opportunities for participation have been developed in school since the 1990s, principally through the increase in pupils' rights and in the number of pupils' representative bodies. These different levels of interest in pupil participation reflect the historical conception of the school's role in citizenship training.

First of all, in France, and particularly since the Revolution, the ambition of school has been to form future citizens through a model of political socialization aiming at the transmission and achievement of knowledge to be used once voting age is attained. Secondly, at the same time and over the centuries, all of the informal upper secondary school pupils and students participation practices (associations, think-tank, congregation, newspapers, folk parade, etc.) were and are either controlled or prohibited by the school authorities. Two reasons are advanced for this state of affairs. On the one side, informal participation was considered more as a problem for authorities than as a contribution to daily school life. Restricting it was a means of preventing the pupils from getting out of hand (Caron, 1991; Legois et al, 2007). On the other side, pupils were not considered to be active actors in their schools, thus informal 
participation had no place in school and was not encouraged.

This lasting conception of the role of the school and the place of the pupil explains the resistance that goes hand in hand with the development of pupil participation in secondary school, the minor legitimacy it is granted, and the preference for formal participation. Consequently, while political discourse concerning school makes widespread use of the notion of citizenship, the schools themselves have difficulty in allowing it to be exercised. This chapter deals with the link between school, citizenship and participation. Firstly, it will show that there are three models of citizenship coexisting in secondary education: educational, juridical and political. Why do they exist and to what social and political developments do they refer? On what definition(s) of citizenship are they based? This chapter illustrates that citizenship in school is expressed through formal participation which is often supervised by adults. Secondly, the implementation of the political and juridical models will be analysed. How concerned are pupils and how are they involved? Do they face limits and problems? Does the reality of differing definitions of citizenship and tools to make pupils be and become citizens have negative effects on adult and pupil involvement in school?

\section{Citizenship as a subject of training}

In France, citizenship training i.e. the acquisition of knowledge and skills required to exercise the future role of citizen lies within an intellectual tradition linking education with access to citizenship and more generally with the training of the individual. This training favours a transmission model based on a process of internalisation of social and civic norms. Moreover, this definition of the school's role is also linked to French political history. During the revolutionary period, citizenship crystallised the debate and become a central reference. It constituted at the same time the foundation and the future perspective of the new regime, using school to legitimise the principles of political sovereignty and prepare its future actors. 
School, henceforth compulsory, had to afford the challenges of bringing individuals into the 'community of citizens', leading them to recognize themselves as members of the nation (Schnapper, 2000) and emancipating them from traditional socialization spaces such as family and Church.

From this perspective the civic education plan, ratified an Act on the $28^{\text {th }}$ of March 1882, was of vital importance. Inspired by Enlightenment philosophy and the ideas of Condorcet; this school subject aimed to develop in children a 'love for the Republic, France, the Fatherland and the State'. Civic education was based on the transmission of knowledge relating to institutional functioning, the rights and duties of citizens, and their expected moral and political behaviour (Deloye, 1994). According to these political preferences, from then on school was in the position to contribute to 'the moral training of the country', as Emile Durkheim emphasized in Education and Sociology (1922). As a 'little society' (Durkheim, 1925), school is the place of education i.e. of preparation for generations "not yet ripe for social life'. While the choices made during the Third Republic asserted the School's role in training citizens and clarified this in terms of format and content, many changes have since been made, concerning both the level of interest accorded to this mission and to its implementation. Consequently, while the question of citizen training is always present in educational policies, the contexts of mobilization for this objective, the political and social expectations expressed on the subject, and the public structures involved have become distinctly more complex.

Contemporarily, the reference to citizenship echoes social phenomena that are relatively heterogeneous yet all point to problems in regulating how secondary schools operate and how pupils' behave.

On the one hand this issue considers the deterioration of the climate in schools, the increase in 
incivility and school violence, and the weakening of teachers' authority; on the other hand it takes into account participation by the pupils, the assertion of their rights and their demands for dialogue, involvement and justice expressed in their protests. The legal texts, the 1989 Orientation for School Act followed by the 2005 Orientation and Programme for the Future of the School Act continue in line with the republican project, conferring on the school the mission to prepare the child for 'the exercise of his/her responsibilities as a (wo)man and a citizen', but the practices of citizenship in schools have become more and more diversified. Citizenship is no longer simply defined in terms of the evolution and the future of the individual but now arouses 'expectations in the present' (Barrère and Martucelli, 1998). This results in different conceptions of citizenship and along with the transmission approach, the introduction of a participative method favouring practice as a way of constructing civic knowledge and skills and as a means of regulating pupils' behaviour in situ. At present there are three approaches to citizenship in secondary education. These have specific objectives and are organized around particular methods, but they all lie within a dual temporality: the present time of school life and the future time of voting age.

\section{Citizenship: three models to the same concept}

The first model is disciplinary and based on the transmission of knowledge. The introduction of civic and moral education by Jules Ferry at the end of the $19^{\text {th }}$ century laid the foundations of the citizenship-training programme. Though it was perpetuated by successive political regimes, the disciplinary model changed its name and organization. It either gave rise to a separate subject or was included in the history/geography syllabus. In France today citizenship training exists throughout school education. In primary and lower secondary schools it forms part of the 'common base of knowledge and skills' introduced in 2006 and refers mainly to the acquisition of a 'humanist culture' (history, geography, literature and arts) 
and of social and civic skills (topics such as rights, duties, responsibility, freedom, principles of the State and institutions).

In upper secondary schools it comes under civic, juridical and social education (ECJS) and is taught by history/geography teachers. ECJS content deals with topics like the State, the public institutions, political and social life, armed forces and security, and ethical questions. The disciplinary model shows two dimensions: a behavioural dimension which is central in the first stage, conveying the notion of 'living together' (Raveaud, 2006) and a cultural dimension focused on the transmission of the formalized knowledge concerning the existing social, economic and political order, and also on the will to take account of current events. Active teaching methods such as debating and discussion are increasingly given preference.

The second model is grounded on a juridical approach, rooted in school rules. Transmitting the rules of common life implies measures regarding teaching organization, school discipline, pupils' rights and obligations and so forth. The juridical model has achieved a growing role in regulating the running of schools. This development reflects the demand for law and order expressed by teachers and principals due to the increasing school violence and the difficulty in exercising authority. It also reflects a more global change in the position of the school towards the law. Up to the end of the 1980s, disciplinary measures taken by schools were regarded as 'internal measures'; however legal problems regarding the wearing of religious signs and the application of the principle of secularity have linked the school to general legal principles. In order to pride itself on being a space of rights and duties, justifying the pupils' respect of these, school could no longer remain a space ruled by customary law. School rules were therefore changed and their legality monitored more strictly. Together with the regulation of duties and sanctions the rights of pupils have been gradually promoted and incorporated in law. These rights have been growing since the early 1990s. Changes were 
facilitated due to the 1989 Orientation for School Act, and the International Convention on Children's Rights adopted by the United Nations in 1989 and subsequently ratified by France in 1990. These texts define the 'rights' enjoyed by pupils and 'children'. In continuity with this and following an upper secondary school protest movement, the rights of publication, association and meetings were recognized in 1991. When these public rights entered upper secondary schools, some limits were set in consideration of the specific features of schools. In July 2000, in order to bring previous choices into coherence and recall the importance of this text in school life, the secondary schools rules were revised (Merle, 2005). The juridical model thus frames the school community while focusing on the status of the pupils within it. It states the nature of the legal relations between pupils and institution by defining duties, rights and norms of justice.

The third model is political and sprang from the concept of 'school life' that appeared after the Second World War. In October 1945 a circular stipulated the existence of 'class leaders representing pupils in the permanent sections of the councils and administrative offices'. It took some twenty years for the second stage to be reached with the creation of the role of class delegate, and pupils' clubs in 1968. The admission of pupils to staff meetings provoked opposition from teachers and school principles fearing a loss of power. The creation of the Établissement Public d'Enseignement Local (local state school) in 1985 included a reassertion of the role of the class delegate on school boards. The 1989 Orientation for School Act proposed the creation of pupils' delegate council, an assembly of all class delegates; this last assembly did not come into existence until November 1990. The first stage of consultation with pupils was later completed through a series of texts. In 1991 the academic upper secondary school committee was created, then in 1995 the national upper secondary school council. The final implementation took place at local level: the upper secondary school pupils' life council was created in 2000 and the pupils' delegates committee was replaced by 
the pupils' delegates' conference, followed in 2004 by the general assembly of pupils' delegates. The political model is fully developed in upper secondary schools. In lower secondary education it is restricted to pupil representation in staff meeting and in the school board. The political model is based on a definition of the school as a political city to which its members are committed. Via school, pupils come to be granted the status of citizens.

This presentation of the three models highlights the coexistence of different approaches to citizenship and the role of the school in building civic behaviour. The disciplinary model meets the traditional objective of citizen training, citizenship being exercised at voting age. The other two models regard the pupil not as a citizen in evolution but as a fully active citizen. The pupil is duty-bound to act within a legal framework of rights and duties, and can exercise political power through voting or eligibility. Thus citizenship is exercised without 'preparation'. However this distinction between the three models does not mean that the boarders between their respective aims are clear. Civic education was actually re-launched with the purpose of improving the atmosphere in schools. Successive governments assumed that learning about institutions and behaviour had to have a direct impact on the everyday school life. The existence of three identifiable models raises the question of their interaction, and with their adequacy concerning the school's operation and the pupils' place in it. Pupil participation is seen primarily within the juridical model which allows them to publish newspapers, carry out projects in the socio-educational club or pupils' club, or to create inschool associations, and within the political model which allows the pupils to represent their classmates and execute projects via the pupils' councils or via the 'Health and citizenship education committees'.

Participation through the juridical and/or the political model is grounded in the idea of formal participation. It always takes place in an institutional framework that allows school principals 
to monitor activities if they so wish. Consequently, it is quite difficult for secondary school pupils to develop informal participation. For example, if they want to organize a carnival, a year-end party or a concert, they have to submit the project to the pupils' delegate committee in order to obtain authorization. This procedure is not only related to issues of liability and safety but it also reflects an approach of pupil's participation.

In reality, if the development of those opportunities in response to present-day school evolution can be considered as a positive orientation for pupils, the way they are framed and implemented also shows a certain ambiguity. Anne Barrère and Danilo Martucelli (1998) underline the tension between the logic underlying the models of citizenship and the youth experience in school life. They stress the existence of a form of 'expressive individualism' and school utilitarianism in a state of tension with school integration and collective action. Pupil participation is apparently all the harder to develop as it is based on the gap between the highly valued standards of action and the pupils' real experience. Pupils are supposed to behave like autonomous, responsible individuals, but at the same time they are maintained in an infantilizing position: they should behave like citizens without being treated as such (Xypas, 2003). This hiatus is clearly evident in surveys on pupil participation in secondary schools.

\section{Being a citizen at school: conditions and limits of participation practices}

In 2004 a quantitative survey, carried out by the French Ministry of Education among final year upper secondary school pupils, aimed to measure participation practices in and outside schools (Guillaume and Verdon, 2007). This survey is quite important because there were no national quantitative measure of pupils' participation. Most of the surveyed pupils (84\%) had taken part to at least one activity in 2003-4: four out of ten (43.6\%) had partaken in activities 
both inside and outside their schools; one out of three (35.2\%) in external activities only, while a small minority (4.9\%) was only active inside their school. Nevertheless almost half of the pupils participated in group activities in school, either in the socio-educational club, the pupils' clubs and the representative bodies. Only $13 \%$ of them have experienced responsibly, the others are simply participant by being there. The Ministry of Education survey shows that there is consistent pupil participation but other qualitative studies are more critical towards participation conditions and the practices that ensue.

In relation to formal participation appropriate to the political model, even if the pupils are informed and vote in the class delegate elections at the beginning of school year, their interest in this kind of participation is different. Upper school pupils express unequal desire to participate or else justify their defection by mentioning study requirements or extra-school activities. The lack of desire reflects the declining importance attributed to the representative's role, while study requirements echo the amount of schoolwork and the need to pass the baccalaureate exams. Pupils elected as delegates also put such arguments forward. Surveys highlight six different reasons to stand for election. There are three main reasons: the 'vocation', the 'continuity', the 'distinction'. The other three are secondary reasons: the 'integration', the 'curiosity' and the 'sacrifice' (Becquet, 2005c; Becquet, 2009a). Concerning 'vocation', pupils insist on their interest for this function. They think they are 'made for' being pupils' delegates who can represent the other pupils. They also explain their candidacy through their wish to help pupils and solve problems in their classroom.

'Actually, I repeated my second (first year of upper secondary school) and last year I was in a quite chaotic class... Pupils' delegates did not do their job very well... Actually, the class was really... it was really a shame... the whole year long. It was really a disaster. You know, I wanted to stand for election to try and solve problems that 
may arise in the classroom.'

'What I like most about the position of delegate is that you can attend the class council. There we get to know what they think of us, what they dare not tell us and what they say between teachers. (...) It is mainly to defend the class and compare our viewpoints. To come, discuss and try and reach an agreement.'

'Continuity' concerns pupils who have a genuine interest in the position and whose first experience becomes part of a continuous process. Each year they stand for election because they have the 'vocation' and are not disappointed with their previous experience. 'Distinction' is eventually referred to the specific position in the classroom gained from being a delegate. Pupils insist on their proximity with adults and their access to information on the school's management.

'Actually, it's because I'm curious. I like to know what's going on in my upper secondary school. Yes because we do not know everything. Students do not know everything and for me it was a kind of curiosity at the beginning. Then I grew more and more interested by the school board. And there are the adults. They talk a lot about positions, budget. I'm interested in this. I like all that stuff out there, all they can do for us. It's true that I enjoy taking part into this.'

The three other reasons that explain standing for election are less present in pupils' interviews but show how they use this function. First, pupils refer to 'integration' when becoming a delegate helps them discover their new school and meet the other pupils. Second, they quote 'curiosity' when they were not interested in this function during lower secondary school, but grow more interested when arriving in upper secondary school. Reference to curiosity is also linked to the creation of the pupils' delegates committee in 2000. Some pupils who were not 
interested in being pupils delegates in the classroom decided to join this new council. Third, some pupils compare their candidacy to a 'sacrifice' because on election day, nobody wanted to become pupils' delegate. As a consequence, they decided to stand for election.

When they stand for election, they declare a wish to be useful to others, a certain taste for responsibility, a desire to have a relationship with the adults in the school other than educationally, and having access to information (Guillaume and Verdon, 2007; Becquet, 2009a). They hold a genuine interest in the position and in some cases the experience becomes part of a continuous process.

Despite this, the work of François Dubet (1991) and Patrick Rayou (1998) came to a relatively pessimistic conclusion on formal participation. They insist on the hazardous or even unlikely nature of the interplay between roles, the role of pupil and that of pupils' delegate, wherein outlines are blurred. They describe a school experience characterized by tension and trials, in which delegates are placed in uncomfortable situations leading to conflict or renouncement. Class delegates are in a difficult position due to three conflicting aspects. The first concerns the definition of the pupils' delegate mandate. Pupils' representatives in a class council or on a school board often stress the vagueness of their role and the consequent difficulty in knowing what exactly their activity involves. Many difficulties emerge among schools, ranging from the single transmission of information to representation of pupils demands.

'Yes, it's a little bit discouraging. I'm involved in this council since three years. We must persevere or we'll never succeed. By dint of trying we get there a little more. In spite there's an improvement. Anyway, he [the principal] will have to adapt. And even if it doesn't please everyone, we try to move forward. We try to do things. Even if we do not succeed, you have to convince that it works. We mustn't give up. ' 
'If there was something concrete, we could say we had done something for the school. We have to stop talking and do something concrete. Two years that it exists. There is nothing. It's hard. We worked but it was unsuccessful. ‘

When pupils describe their function, they point out different types of activities (Becquet, 2005c). Pupils' delegates work in class council is organised around three phases: first, before the class council meeting, delegates try to grab information from pupils about the atmosphere of the classroom, their teachers and, individually, on personal situations that can help them to defend pupils; second, during the class council meeting, they take notes on individual assessments made by each teacher and they try to intervene to explain pupil's specific situations; third, they give collective or individual feedback to pupils of their classroom. In the other councils where pupils are represented, the work is quite different. In the school board, meetings deal with administrative and financial issues. Pupils' delegates only attend meetings and are present to give the 'pupils' point of view'. In the pupils' delegates committee, which is focused on everyday school life, during official meeting delegates communicate pupils' demands and suggest facilities to improve pupils' life and organise different projects. Between two meetings, they also work together on projects.

'Right now for example, I make them fill individual sheets for the class council in relation to their personal problems or school work problems. There are many pupils who don't write anything on the form but who come to me and tell me things. But they do not necessarily want me to speak about this during the class council meeting.'

'During the meeting, the teachers ask me what I think about the class. I say what I think about the pupils who have problems, about the scholar level of the pupil. And then, when they examine the case of each pupil, well I say what I think, if I agree or not 
with teachers and after I write all the information I have, what the teachers say about each pupil and I fill a sheet for each pupil with what they think about his behavior.'

'They usually come to me after the class council meeting. When I see our teacher, she exposes everyone's problems in public. Everyone in the class does not like that. For example, there are two that have behavior warnings and she told people names. Everyone said it's nobody's business, that was personal, but she really insisted and she said it.'

The second concerns the possibility of speaking in representative bodies and asserting the pupils' point of view. While the inequality in pupils' expression is linked to their personalities, it also relates to the contexts in which they speak. Because of the formal nature of the meetings and the difficulty in defining the subjects to debate, pupils sometimes fail to speak (Becquet, 2009a). Thus in class councils dealing with exam results and pupils' behaviour, defending the pupils is not easy; and in upper school councils, many subjects are bypassed in order to avoid conflict. Consequently the pupils' delegates have difficulty in expressing their points of view, a difficulty that increases in case of disagreement with adults' opinion.

'Especially we have a principal that, even if, he leaves us talk... well let's say that. We decide but sometimes we feel that he would like to influence us a little bit and it's sometimes a little unpleasant. We would like to be able to decide alone among pupils. And it happened once that a delegate told him "listen is up to us and ...» Politely I mean...But sometimes it's a bit annoying because the principal is still ... He represents the authority. It's not easy to get in front against the principal.' 
'During the class council we can speak but I don't do it often. I'm intimidated by all the teachers and as the other delegate is not present... But if there is anything that seems important to me I am telling it. When all the teachers are talking I prefer not to take the floor.'

The third relates to the risks run by pupil delegates, who often fear of receiving poorer marks or negative feedback by their teachers. Delegates with poor or average results in schoolwork, or who criticise school and campaign for improvements in study conditions particularly feel this. The sense of risk also concerns relationships with other pupils in the class, who sometimes consider class delegates as allies of the adults against their peers. This dual discredit does not always encourage pupils to participate in representative bodies, especially in becoming class delegates. These three aspects clearly raise the issue of the legitimacy of institutional participation by pupils. It is encouraged by the Ministry of Education yet not given equal support in schools. Between a school where the principal and teaching staff are in favour of it and one where they are not, there is a real contrast in terms of participation dynamics and activities performed.

Regarding the juridical model, the analyses throws light on the concepts of the law working in schools, particularly the primacy of respect for teaching and public order over the expression of individual rights, and the persistence of a hierarchical relationship among the actors in the school community. They also point out the gap between the reality of a right and the pupils' poor awareness of it, even the existence of a discrepancy between this reality and the pupils' idea of their own rights within the school. Thus when the schools rules seem out of keeping with the experience of pupils in lower and upper secondary education, they question the honesty and therefore the legitimacy of these rules. They don't reject the principle of the right but the way it is put into practice (Merle, 2005). Such disparities between formal and actual 
rights are seen in studies handling the experience of upper school journalists, who are not always acquainted with the texts governing the right of publication. They complain about the impossibility of covering certain topics such as everyday school life or politics, and about acts of censorship. Their judgement of the fairness of such decisions is erratic because these are explained insufficiently and without reference to the law. These disagreements show a difficulty in understanding the freedom of expression granted to pupils and a fear that this freedom may be exercised against teaching staff. The problem relates more generally to issues about how the respective positions of the actors are perceived and about conceptions of order in school, rather than to strictly legal questions (Becquet, 2003). As with institutional participation, the question arises from the legitimacy of pupils' participation via the publication of a magazine. The right of self-expression, exercised within the framework of a representative body or in writing, clashes with a school organization struggling to position itself and accept this right in all its dimensions. For example in high second school pupils' newspapers, it is not always possible to speak about politics or school running. On the one hand, pupils decide not to talk about politics because it is not the editorial line of their newspaper but also because they do not want to share their personal opinions or fear to give rise to reactions in the school: 'at the beginning we did not have a particular ideology in the newspaper. We said that we did not want to do something political, we do not want controversy. So it was at the political level, addressing the news but remaining, giving his opinion but I mean not drawing the crowds. It's not that this is not a political paper, but we did not want that there were really specific ideas linked to a political movement. '.On the other hand, they refuse to talk about school life and, in particular about teachers, because they do not find it interesting or fear being accused of defamation: 'it's not our type to talk about teachers. Making fun for example. If I want to make fun of a teacher, I do it in class, not in the newspaper. While it is true, pupils expect it a little bit. But this is not our goal. ' (Becquet, 
2003).

It's hardly surprising that pupils fail to see their school as a living space, where they can take part in associations. On this point, although practices in schools have not been extensively studied, pupils have access to activities, mainly sports and cultural, but only rarely do they help to develop these activities. They often prefer to be involved in associations outside of school.

Surveys do not analyse the relations between those different models of formal participation but findings show that there are not in actuality linked to each other. Pupils' participation is based more on these three ways of defining and implementing citizenship in school than on an integrated mode.

These models are complementary however or, at least in some aspects, overlapping. The school experience is mainly structured by the juridical and political models through the application of school rules and the presence of pupils' representatives. Through them, pupils face situations that contribute to their political socialization and build opinions and behaviours concerning citizenship. If the implementation of these models is not consistent, or gives rise to inconsistencies between the models, the legitimacy of the reference to citizenship may be invalidated. For example, if on the one hand, pupils have a right of expression integrated in the school rules and, on the other hand, pupils delegates are unable to express their demands or their discontent, they highlight the gap between principles and reality and reveal that the right of expression is a formal rather than a tangible right, or that the election of class representatives is unnecessary because they possess a minimum prospect of performing their function from the pupils perspective. Therefore, through such a situation, several of the principles and mechanisms of citizenship are weakened. Examples of tension between the juridical and the political models can be multiplied. The risk of inconsistency becomes more 
important when the disciplinary model is taken into account. Indeed, the situation described refers to principles and practices that civic education promotes. As the aim of this program is to provide standards of behaviour, pupils must be convinced of the value of rights and duties and of the benefits of the democratic model and, for example, of the need to vote to choose their representatives. However, if the school fails to implement the standards they value, pupils may question their legitimacy. Various media has already provided them with knowledge of political and social life, and to show a certain distrust of politicians and political institutions. If the encountered situations and their implementation contradict (perhaps) the principles that they are expected to endorse as citizens, they also question pupils' positions. In the disciplinary model, pupils learn how to become a citizen and have a rather passive attitude. In the juridical and political models; they exercise their citizenship and are encouraged to be active. The transition from one posture to another, from the pupil who receives information to the pupil who have to speak, express opinion or defend the other pupils, is not always obvious. It takes place in a similar context, the school environment, but in a different situation, one side a teaching situation (the class), the other a political situation (the class board council for example).

The discrepancies between the three models also result from the existence of different conceptions of the role of school in building citizens and the means to achieving this conception. These disagreements, when expressed inside the same school, do not promote the legitimacy of the three models, nor do they facilitate pupils' participation. Nevertheless, the lack of an integrated model of citizenship is the result of the political choices that frame the references to citizenship in school. As stressed in the description of the three models, the different tools have been implemented more often than not through problem solving logic rather than through the logic of building civic skills and the integration of pupils in daily school life. In many ways, the notion of citizenship was gradually manipulated and the tools 
and practices required are now segmented.

The implementation in 2006 of the 'common base of knowledge and skills' in primary and lower secondary education can be seen as a means to foster an integrated approach to citizenship in schools. Indeed, three skills refer to the training of citizens and can be compared with the three models: 'humanistic culture' that 'contributes to the formation of judgment, taste and sensitivity and can acquire markers', 'the social and civic competences' which aims 'to master, as an individual and as a citizen, the basic rules of social life and to implement them in schools' and 'autonomy and initiative' skill which aims towards independence and then carrying out of projects across the school. However, the skills approach is not easy to implement in an educational system that values sheer knowledge above all else. It involves thinking about the relationship between knowledge and skills and the process of acquiring these skills and the evaluation of these processes. In addition, the school promotes some implicit social skills and excludes others that are structuring youth experiences, such as rituals and rules between pupils that adults unevenly master (Gasparini, 2008) or external practices. An integrated approach to citizenship needs to build a bridge between the three models, youth life and the acquisition of common base skills in order to highlight their continuity. This work requires a reflection on the contribution of school education for citizenship and its relationship to out of school civic practices and to supposed collaboration among and between educational professionals.

\section{Conclusion}

The analysis of pupils' participation in schools clearly highlights that the way in which French public secondary schools define and implement citizenship and pupil participation introduces various misunderstandings concerning pursued goals and the degree of pupil participation. Firstly, it seems that there is a contradictory positioning of the school towards 
pupil participation, participation that is simultaneously encouraged and discredited. If training citizens is part of school goals, the way the numerous measures and programs were integrated and used in daily-life school progressively made principals, teachers and pupils either more suspicious or less interested in those opportunities. Moreover, the frequent references towards citizenship as a vehicle in solving school problems and the confusion between citizenship and civility have weakened its signification. Secondly, the coexistence between three models of citizenship raises two problems. On the one hand, the implantation of each one is not easy because the school's organisation, rules, standards, and the adult and pupil positions are tested and there is not necessary any agreement on these elements. One the other hand, as there is no integrated model of citizenship in secondary school, tensions or contradictions between them can arise. Thirdly, the varying degrees of legitimacy granted to pupil participation have repercussions on pupils' interest and involvement. It can be noted that pupils' expression is more often transferred to areas outside schools. The recurring upper secondary school protests are evidence of this. Although they are organized in reaction to proposals for educational reform and addressed to national government, pupils' claims are also linked to daily school life (study conditions and relationships with teachers for examples). They could be expressed beyond the grasp of pupils' representative bodies but it seems to be more difficult to be heard in them. Pupils, like young people in general (Becquet, 2009b; Muxel, 2010), prefer using direct means of expression like demonstrations, strikes (which are 'prohibited' because pupils are not considered to be workers), or sit-ins. On this point, school participation seems to be disconnected from other forms of participation, which young people regard as more legitimate. All those elements should be taken into account because participation in schools is a contribution to political socialization. In surveys among voluntary workers or militants, primary experiences in school are frequently spotted. Such experiences, when they occur in good conditions, leave visible traces in personal biographies. It is highly likely that 
discrediting them will have the opposite effect and nourish mistrust of commitment to the community.

\section{References}

Barrère, A. and Martucelli, D. (1998) 'La citoyenneté à l'école : vers la définition d'une problématique sociologique' ('Citizenship in school: toward the definition of a sociological problem'), Revue française de sociologie, vol 34, no 4, pp 651-671.

Becquet, V. (2003) 'Les journaux lycéens entre droits et infractions' ('Students' newspapers between rights and offences'), in G. Hénaff and P. Merle (eds), Le droit et l'école. De la règle aux pratiques (Law and school. From rule to practices), Rennes: Presses Universitaires de Rennes.

Becquet, V. (2005a) 'Dialoguer avec les jeunes : un engagement réciproque ? Les conseils de la vie lycéenne et les conseils de la jeunesse' ('To dialogue with young people : a reciprocal engagement? the high secondary school councils and the youth councils'), in V. Becquet and C. De Linares (eds) Quand les jeunes s'engagent. Entre expérimentations et constructions identitaires (When young people engage themselves. Between experimentations and identity buildings), Paris: L'Harmattan, pp 107-126.

Becquet, V. (2005b) Les conseils de la jeunesse à Paris. Atouts et difficultés d'un dispositif de démocratie participative (Paris youth councils. Assets and difficulties of an attempt of participative democracy), Rapport de recherche, Paris: CAFI.

Becquet, V. (2006) 'Participation des jeunes : regards sur six pays' ('Youth participation : analysis in six countries'), Agora Débats Jeunesses, no 42, pp 14-29.

Becquet, V. (2009a) 'Se saisir du conseil de la vie lycéenne : des principes à l'exercice de la fonction de délégué' ('To use the high secondary school council: from principle to reality'), Carrefours de l'éducation, no 28, pp 65-79.

Becquet, V. (2009b) 'L'engagement des jeunes dans l'espace public' ('Young people's engagement in public space'), in B. Roudet (ed) Regard sur les jeunes en France, (Analysis on young people in France), Laval: Les Presses de l'Université Laval, pp 103-122.

Caron, J.-C. (1991) Générations romantiques. Les étudiants de Paris et le quartier latin 
(1814-1851), (Romantic generations. Paris' students and the quartier latin (18141851)), Paris: Armand Colin.

Deloye, Y. (1994) Ecole et citoyenneté. L'individualisme républicain de Jules Ferry à Vichy: controverses, (School and citizenship. Republican individualism from Jules Ferry to Vichy: controversies), Paris: Presses de la FNSP.

Dubet, F. (1991) Les lycéens (High secondary school pupils), Paris: Seuil.

Durkheim, E. (1925) L'éducation morale, (Moral education), Paris: Presses Universitaires de France.

Durkheim, E. (1922) Education et sociologie, (Education and sociology), Paris: Presses Universitaires de France.

Gasparini, R. (2008) 'Compétences sociales des élèves', ('The social competencies of pupils'), in A. van Zanten (ed), Dictionnaire de l'éducation, (Dictionary of education), Paris, Presses Universitaires de France.

Guillaume, J.-C. and Verdon, R. (2007) Pratiques citoyennes des lycéens dans et hors de l'établissement, (High secondary school pupils' citizenship practices in and out school), Les dossiers Insertion, Education et Société, Paris: Ministère de l'éducation nationale, de l'enseignement supérieur et de la recherche.

Legois, J.-P., Monchablon, A. and Moder, R. (eds) (2007) Cent ans de mouvements étudiants (A century of students' movements), Paris: Syllepse.

Loncle, P. (2008) Pourquoi faire participer les jeunes? Expériences locales en Europe, (Why should young people participate? local experiences in Europe), Paris: L'Harmattan.

Merle, P. (2005) L'élève humilié. L'école, un espace de non droit?, (The humiliated pupil. School as a non-right space?), Paris: Presses Universitaires de France.

Muxel, A. (2010) Avoir 20 ans en politique, (Being twenty years old in politics), Paris: Seuil.

Raveaud, M. (2006) De l'enfant au citoyen, (From the child to the citizen), Paris: Presses Universitaires de France.

Rayou, P. (1998) La Cité des lycéens, (The city of high secondary school pupils), Paris: L'Harmattan.

Roudet, B. (2004) 'Entre responsabilisation et individualisation: les évolutions de 
l'engagement associatif', ('Between responsibility and individualisation : the evolutions of associative engagement'), Lien social et politiques, no 51, pp 17-27.

Schnapper, D. (2000) Qu'est-ce que la citoyenneté ? What is citizenship ?), Paris: Gallimard. Xypas C. (eds) (2003), Les citoyennetés scolaires, (School citizenship), Paris: Presses Universitaires de France. 